\title{
Distribution of Hydatidosis and its Economic Significance in Domestic Small Ruminants in Selected Abattoirs in Belgut, Kenya
}

\author{
Chepkirui Evalyne ${ }^{1}$ and Ngetich Wyckliff ${ }^{2 *}$ \\ ${ }^{1}$ Department of Clinical Studies, University of Nairobi, Nairobi, Kenya \\ ${ }^{2}$ Department of Clinical Studies, Egerton University, Egerton, Kenya
}

*Corresponding author: Wyckliff Ngetich, Department of Clinical Studies, Egerton University, Egerton, Kenya.

Received Date: July 15, 2019

Published Date: July 31, 2019

\begin{abstract}
Ecchinococcus tapeworm has a complex life cycle involving two hosts; intermediate (herbivores) and definitive as dogs or wild carnivores. The larval stages infect visceral organs of herbivores and humans and develop into fluid-filled cysts that exert pressure to these organs interfering with their normal physiological functions. Identification of the cysts is normally made during post-mortem meat inspection leading to condemnation of infected organs for aesthetic purposes.

A retrospective study was carried out in Belgut Sub-county, Kericho County by reviewing slaughterhouse data for the period between 2012 and 2016 to identify organs of small domestic ruminants condemned due to hydatid infections. Records from six selected abattoirs were reviewed and the number of organs condemned tabulated. Simple statistics of percentage and proportions were done and associated economic value computed based on the monetary value of each organ condemned during this period.

A total of 35,771 sheep and goats were slaughtered in the 5- year study period; $22.21 \%$ (7943/35771) sheep and 77.79\% (27828/35771) goats. For sheep, a total of 267 livers and 215 lungs were condemned, whereas for goats; 710 livers and 646 lungs were condemned for harboring hydatid cysts. Annual prevalence of infection was calculated and it was found out that the trend is generally reducing. From ovine organs condemned, a total of KSh 58,775 was lost while KSh 158,150 was lost from condemned caprine organs giving a total of KSh 216,925 for the five-year study period. From these findings, it is evident that Hydatidosis is still a challenge in small stock industry in Belgut Sub-County as it is one of the main causes of organ condemnation. Liver and lung of sheep and goats were the only organs found to be infected in this study and these led to their condemnation and hence direct economic losses to butchers. Therefore, regular deworming of dogs, proper and strict disposal of rejected/condemned organs as well as public education to increase awareness on parasitic zoonoses are recommended to reduce the burden of this parasite and the possible crossover to humans.
\end{abstract}

Keywords: Sheep; Goats; Hydatidosis; Prevalence; Belgut

\section{Introduction}

Ecchinococcus is a tapeworm of dogs whose larvae cause hydatidosis disease in ruminants and is zoonotic [1]. The parasites lifecycle involves herbivores as intermediate hosts and dog or wild carnivores as the definitive hosts [2]. The worm resides in the small intestines of dogs while the larval stages in ruminant/human viscera [3]. Dogs pass out the parasite eggs in faeces contaminating pasture where ruminants ingest during grazing. The eggs hatch in the gastro-intestinal tract, penetrate the intestinal wall and spread through bloodstream to organs including liver, lung, heart, kidney and spleen and form fluid-filled cysts exerting pressure to these organs [4]. The infection does not manifest clinically, and detection of these cysts is commonly during meat inspection. Home slaughter of animals and feeding of infected viscera to dogs as well as improper meat inspection favours propagation of this parasite [5]. The effects of this infection in livestock include infertility, poor carcasses, reduce production and condemnation of organs during post-mortem meat inspection [6,7]. A number of studies in Kenya have been carried out in pastoral communities like Turkana and Maasai with large herds of cattle, sheep, goats and camels $[4,8]$. In a study carried out by [9] in Kitengela and Suswa abattoirs, an 
estimated prevalence of $10.8 \%, 16.5 \%$ and $25.8 \%$ was observed in goats, sheep and cattle respectively citing high levels in the liver.

Man is incidentally infected by ingesting contaminated food or water and is a dead-end host though exceptions have been reported where dead are not buried and dogs or wild carnivores access the infected cadavers consuming hydatid cysts [10]. Human develop two forms of hydatidosis, cystic echinococcosis (CE) which is the most common [11] and alveolar Ecchinococcosis (AE) [1,12]. Economic losses of Hydatidosis in humans occur as a result of expensive diagnosis and treatment as well as fatalities [13]. A lot of research has been done on infections in humans but still it is a threat to human health as well as livestock production in Arid and Semi-Arid Lands of Kenya (Odero, 2015).

A study was therefore designed to determine the occurrence of this parasite in small domestic ruminants and analyze the associated economic losses in Belgut Sub-county, Kenya. Such would provide useful baseline data to inform control measures for the parasite and better minimize its transmission risk to humans.

\section{Materials and Methods}

\section{Description of study area}

The study was carried out in Belgut Sub-county, Kericho County. The population of the sub-county is 100,325 persons [14] with the headquarters in Sosiot. The Sub-county's climate is classified as warm and temperate with average temperature of $18.1^{\circ} \mathrm{C}$ and approximately $1735 \mathrm{~mm}$ of rainfalls annually. The main economic activities include Tea plantation, livestock keeping, sugar cane farming, horticulture and small-scale trading.

The prevalence and economic importance of hydatid cysts infection in domestic small ruminants was determined using annual meat inspection reports sent to department of Veterinary Sub-county headquarters. The data was reviewed from six selected abattoirs that had consistent available data for the study period. These are Sosiot, Kiptere, Kapsoit, Kabianga, Kapkelek and Kapsuser. The data included the annual total number of domestic small ruminants (sheep and goats) slaughtered, number of livers and lungs condemned due to hydatid infection and associated economic losses. The information in the Table 1 was used to calculate the revenue lost due to condemnation of hydatid infected livers and lungs (Table 1).

Table 1: Estimated average weight of organs of slaughtered animals and their market prices (Adopted from Odero, 2015).

\begin{tabular}{|c|c|c|c|c|}
\hline $\begin{array}{c}\text { Animal } \\
\text { Species }\end{array}$ & Organ & $\begin{array}{c}\text { Average } \\
\text { Weight (kg) }\end{array}$ & $\begin{array}{c}\text { Price Per } \\
\text { kg (ksh) }\end{array}$ & $\begin{array}{c}\text { Total Price per } \\
\text { Organ (ksh) }\end{array}$ \\
\hline Sheep/goats & Liver & 1 & 200 & 200 \\
\hline & Lung & 0.25 & 100 & 25 \\
\hline
\end{tabular}

\section{Sampling}

The domestic small ruminants slaughtered in these abattoirs were brought by trekking or transport by road through livestock trade system from within the Sub-county and from neighboring sub-counties including Soin-Sigowet, Ainamoi, Bureti and Border Counties like Bomet, Nakuru, Nandi, Kisumu and Nyamira.

\section{Interview of key informants}

Key informants were interviewed including Sub-county veterinary officer, one meat inspector at sub-county headquarters and five farmers. Simple questions regarding Hydatidosis infection in domestic small ruminants were asked; is hydatid infection still a problem in the area? Possible reasons for the current trend of infection (if increasing or declining), hygienic measures in the slaughterhouses e.g presence of clean water, disposal pits and fencing of the sites, control strategies adapted in the area and level of awareness by farmers.

\section{Data entry and analyses}

The information obtained from the records was entered in excel spreadsheet and simple statistics were calculated including proportions, percentages and totals and presented with tables and graphs.

\section{Results}

\section{Total number slaughtered}

A total of 35771 sheep and goats (shoats) were slaughtered in the six selected abattoirs in the 5- year study period (Table 2). From these, $22.21 \%$ (7943/35771) were sheep and $77.79 \%$ (27828/35771) were goats. The highest slaughter was in the year 2016 of $22.17 \%(7932 / 35771)$ and the lowest being in the year 2012 of $17.02 \%$ (6091/35771).

Table 2: The total number of domestic small ruminants slaughtered in six selected abattoirs in Belgut sub-county between 2012 and 2016.

\begin{tabular}{|c|c|c|c|c|c|c|}
\hline \multirow{2}{*}{ Abattoir } & Year & $\mathbf{2 0 1 2}$ & $\mathbf{2 0 1 3}$ & $\mathbf{2 0 1 4}$ & $\mathbf{2 0 1 5}$ & $\mathbf{2 0 1 6}$ \\
\cline { 2 - 7 } & Species & & & & & \\
\hline \multirow{2}{*}{$\begin{array}{c}\text { Sosiot S/ } \\
\text { HSE }\end{array}$} & Ovine & 301 & 298 & 352 & 394 & 452 \\
\cline { 2 - 7 } & Caprine & 1609 & 1709 & 1832 & 1901 & 1844 \\
\hline \multirow{2}{*}{$\begin{array}{c}\text { Kiptere } \\
\text { S/SLAP }\end{array}$} & Ovine & 280 & 300 & 318 & 341 & 399 \\
\cline { 2 - 7 } & Caprine & 701 & 734 & 801 & 893 & 819 \\
\hline \multirow{2}{*}{$\begin{array}{c}\text { Kapsoit } \\
\text { S/SLAP }\end{array}$} & Ovine & 204 & 184 & 217 & 224 & 259 \\
\cline { 2 - 7 } & Caprine & 332 & 389 & 398 & 404 & 407 \\
\hline \multirow{2}{*}{$\begin{array}{c}\text { Kabianga } \\
\text { S/SLAP }\end{array}$} & Ovine & 101 & 169 & 179 & 205 & 278 \\
\cline { 2 - 7 } & Caprine & 383 & 421 & 459 & 489 & 466 \\
\hline \multirow{2}{*}{$\begin{array}{c}\text { Kapkelek } \\
\text { S/SLAP }\end{array}$} & Ovine & 291 & 294 & 313 & 336 & 387 \\
\cline { 2 - 7 } & Caprine & 1006 & 1302 & 1364 & 1511 & 1348 \\
\hline \multirow{2}{*}{$\begin{array}{c}\text { Kapsuser } \\
\text { S/SLAP }\end{array}$} & Ovine & 82 & 94 & 108 & 209 & 374 \\
\cline { 2 - 7 } & Caprine & 801 & 832 & 874 & 900 & 899 \\
\hline \multirow{2}{*}{\begin{tabular}{c} 
Total \\
\cline { 2 - 7 }
\end{tabular}} & Ovine & 1259 & 1339 & 1487 & 1709 & 2149 \\
\cline { 2 - 7 } & Caprine & 4832 & 5387 & 5728 & 6098 & 5783 \\
\hline $\begin{array}{c}\text { Grand } \\
\text { Total }\end{array}$ & 6091 & 6726 & 7215 & 7807 & 7932 \\
\hline \multirow{2}{*}{$*$} & & & & \\
\hline
\end{tabular}

\section{Ovine organs condemned}

From the data collected for the five years, a total of 267 ovine livers were condemned due to Hydatid infection. The highest number was recorded in the year 2012 of $29.6 \%$ (79/267) and the lowest in 2015 of $13.1 \%$ (35/267) (Table 3). 
Table 3: Number of Ovine liver condemned in the selected abattoirs in Belgut Sub-county.

\begin{tabular}{|c|c|c|c|c|c|}
\hline $\begin{array}{c}\text { Slaughter } \\
\text { house/ } \\
\text { slap }\end{array}$ & $\mathbf{2 0 1 2}$ & $\mathbf{2 0 1 3}$ & $\mathbf{2 0 1 4}$ & $\mathbf{2 0 1 5}$ & $\mathbf{2 0 1 6}$ \\
\hline Sosiot & 22 & 8 & 13 & 9 & 10 \\
\hline Kiptere & 4 & 3 & 8 & 5 & 15 \\
\hline Kapsoit & 9 & 9 & 12 & 4 & 11 \\
\hline Kabianga & 5 & 9 & 3 & 10 & 9 \\
\hline Kapkelek & 32 & 12 & 6 & 7 & 8 \\
\hline Kapsuser & 7 & 2 & 4 & 0 & 11 \\
\hline Total & 79 & 43 & 46 & 35 & 64 \\
\hline
\end{tabular}

Within the study period, 215 ovine lungs were condemned due to Hydatid infection. The highest number was recorded in the year 2016 of $26.0 \%$ (56/215), however, only $13.0 \%$ (28/215) were condemned in the year 2015 (Table 4).

Table 4: Number of Ovine lungs condemned in the selected abattoirs in Belgut Sub-county Caprine organs condemned.

\begin{tabular}{|c|c|c|c|c|c|}
\hline $\begin{array}{c}\text { Slaughter } \\
\text { house/ } \\
\text { slap }\end{array}$ & 2012 & 2013 & 2014 & 2015 & 2016 \\
\hline Sosiot & 23 & 8 & 8 & 8 & 10 \\
\hline Kiptere & 7 & 10 & 9 & 7 & 10 \\
\hline Kapsoit & 7 & 11 & 12 & 6 & 11 \\
\hline Kabianga & 3 & 6 & 3 & 6 & 10 \\
\hline Kapkelek & 3 & 9 & 0 & 1 & 8 \\
\hline Kapsuser & 8 & 0 & 4 & 0 & 7 \\
\hline Total & 51 & 44 & 36 & 28 & 56 \\
\hline
\end{tabular}

On the other hand, 710 caprine livers were condemned within the study period. Comparatively, 2013 (34.5\%; 245/710) recorded the highest number condemned with the least recorded in 2016 (10.4\%; 74/710) (Table 5).
Table 5: Number of Caprine Liver condemned in the selected abattoirs in Belgut Sub-county.

\begin{tabular}{|c|c|c|c|c|c|c|}
\hline Sub-county & $\begin{array}{c}\text { Slaughter } \\
\text { house/slap }\end{array}$ & $\mathbf{2 0 1 2}$ & $\mathbf{2 0 1 3}$ & $\mathbf{2 0 1 4}$ & $\mathbf{2 0 1 5}$ & $\mathbf{2 0 1 6}$ \\
\hline \multirow{4}{*}{ Sosiot } & 66 & 41 & 51 & 26 & 8 \\
\cline { 2 - 7 } & Kiptere & 16 & 21 & 27 & 16 & 16 \\
\cline { 2 - 7 } & Kapsoit & 28 & 39 & 28 & 10 & 15 \\
\cline { 2 - 7 } & Kabianga & 26 & 51 & 14 & 17 & 9 \\
\cline { 2 - 7 } & Kapkelek & 26 & 54 & 10 & 12 & 16 \\
\cline { 2 - 7 } & Kapsuser & 12 & 39 & 3 & 3 & 10 \\
\hline \multirow{7}{*}{ Total } & & 174 & 245 & 133 & 84 & 74 \\
\hline
\end{tabular}

A total of 646 caprine lungs were also condemned within the 5-year period due to hydatid infection. The highest number was recorded in the year 2012 of 32.2\% (208/646); however, 2015 and 2016 recorded the lowest numbers of $11.8 \%$ (76/646) each (Table 6).

Table 6: Number of Caprine lungs condemned in the selected abattoirs in Belgut Sub-county.

\begin{tabular}{|c|c|c|c|c|c|c|}
\hline Sub-county & $\begin{array}{c}\text { Slaughter } \\
\text { house/slap }\end{array}$ & $\mathbf{2 0 1 2}$ & $\mathbf{2 0 1 3}$ & $\mathbf{2 0 1 4}$ & $\mathbf{2 0 1 5}$ & $\mathbf{2 0 1 6}$ \\
\hline \multirow{5}{*}{} & Sosiot & 68 & 47 & 22 & 11 & 12 \\
\cline { 2 - 7 } & Kiptere & 14 & 21 & 16 & 17 & 14 \\
\cline { 2 - 7 } & Kapsoit & 27 & 37 & 28 & 27 & 16 \\
\cline { 2 - 7 } & Kabianga & 30 & 45 & 8 & 20 & 8 \\
\cline { 2 - 7 } & Kapkelek & 30 & 37 & 11 & 0 & 14 \\
\cline { 2 - 7 } & Kapsuser & 39 & 10 & 4 & 1 & 12 \\
\hline \multirow{2}{*}{ Total } & & 208 & 197 & 89 & 76 & 76 \\
\hline
\end{tabular}

\section{Prevalence of organs condemned}

Table 7: Number of domestic small ruminants' organs condemned and proportion of the total slaughter in the period $2012-2016$ in Belgut sub-county.

\begin{tabular}{|c|c|c|c|c|c|c|c|c|c|c|c|}
\hline \multirow{2}{*}{\multicolumn{2}{|c|}{ Organs }} & \multicolumn{2}{|c|}{2012} & \multicolumn{2}{|c|}{2013} & \multicolumn{2}{|c|}{2014} & \multicolumn{2}{|c|}{2015} & \multicolumn{2}{|c|}{2016} \\
\hline & & $\mathbf{N}$ & P (\%) & $\mathbf{N}$ & P (\%) & n & P (\%) & $\mathbf{n}$ & P (\%) & $\mathbf{n}$ & P (\%) \\
\hline \multirow{2}{*}{ Ovine } & Liver & 79 & 6.3 & 43 & 3.2 & 46 & 3.1 & 35 & 2 & 64 & 3 \\
\hline & Lung & 51 & 4.1 & 44 & 3.3 & 36 & 2.4 & 28 & 1.6 & 56 & 2.6 \\
\hline \multirow{2}{*}{ Caprine } & Liver & 184 & 3.8 & 226 & 4.2 & 133 & 2.3 & 84 & 1.4 & 74 & 1.3 \\
\hline & Lung & 77 & 1.6 & 192 & 3.6 & 84 & 1.5 & 76 & 1.2 & 77 & 1.3 \\
\hline
\end{tabular}

$\mathrm{n}=$ number of condemned organs

$\mathrm{P}=$ proportion of condemned organs

The prevalence of the organs condemned due to hydatid infection was calculated for every year by dividing the number of specific organs condemned with the total slaughter for both sheep and goats. Table 7 shows the number of specific organs condemned and the resultant prevalence for each species (Table 7).
As shown from Figure 1, the condemnation of organs due to hydatid infection is generally reducing. Ovine liver condemnation is reducing each year upto 2015, but it increases a bit in 2016 likewise to ovine lung. Caprine liver and lung recorded the highest level of condemnation increased in the year 2013 but the trend generally decreases through 2016 (Figure 1). 


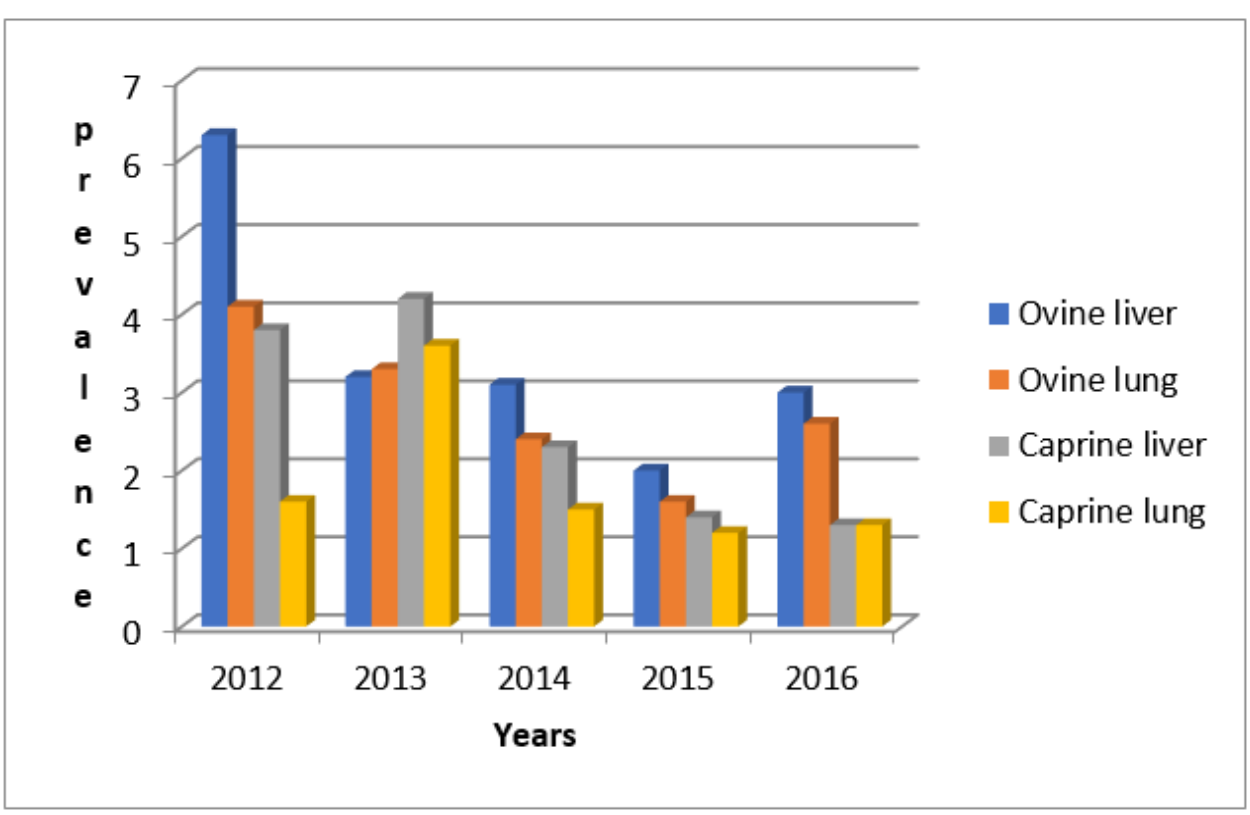

Figure 1: Percentage (\%) proportion of organs condemned due to hydatid infection from 2012 to 2016.

\section{Economic losses due to organs condemnation}

The number of all the condemned organs was tabulated and their prices computed using figure cited by Odero, (2015). From ovine organs condemned, a total of KSh 58,775 was lost while KSh 158,150 was lost from condemned caprine organs giving a total of KSh 216,925for the five-year study period (Table 8).

Table 8: Number of organs condemned and associated economic losses in selected abattoirs in Belgut Sub-county for the period 2012-2016.

\begin{tabular}{|c|c|c|c|}
\hline \multirow{2}{*}{ Species } & Organ & No condemned & Price(ksh) \\
\cline { 2 - 4 } & Liver & 267 & 53,400 \\
\hline \multirow{2}{*}{ Caprine } & Lung & 215 & 5,375 \\
\cline { 2 - 4 } & Liver & 710 & 142,000 \\
\hline $\begin{array}{c}\text { Total revenue } \\
\text { lost }(\mathrm{ksh})\end{array}$ & Lung & 646 & 16,150 \\
\hline
\end{tabular}

\section{Key informant interviews}

The Sub-county veterinary officer observed that meat inspection reports hydatidosis had reduced significantly and was thought to be due to proper disposal of condemned organs, import restriction from other counties and current increase in level of awareness of zoonotic diseases of pets and therefore improve management of pets including vaccination and deworming. According to the meat inspector, hydatid cysts in organs had reduced over time and he attributed this to strict measures on disposal of condemned organs, reduced home slaughter of sheep and goats. However, it was also noted that meat inspector organises meetings with slaughterhouse workers to inform them about the hygienic measures and possible zoonotic diseases associated with slaughter and their control/preventive measures. Two of the five farmers interviewed did not know about hydatidosis and those who knew said that they were deworming their dogs and they had reduced home slaughter of goats and sheep and hence the reducing trend in the level of condemnation. This could be attributed to a number of factors identified during the interview of stakeholders that include, increased level of awareness on parasitic zoonoses and perhaps regular deworming of dogs.

\section{Discussion}

This study showed that there is presence of hydatid infection in domestic small ruminants in Belgut Sub County. Their prevalence $(6.1 \%$ for goats and $4.9 \%$ for sheep) was higher than what was recorded for bovine in Kericho County that was 3.5\% [6]. These findings were similar to a study done in Egypt where cystic ecchynococcosis was more prevalent in sheep (7.1\%) and goats $(13.1 \%)$ than in cattle $(0.1 \%)$ [15]. The prevalence of Echinococcus infection of small ruminants in this study could be due to indiscriminate home slaughter of these species and feeding of offal to dogs and this favors complete life cycle of the parasite. However, other studies have reported contrary findings; In Kenya, Joseph, (2015) reported higher prevalence in cattle (15.0\%) compared to $12.0 \%$ sheep and $6.2 \%$ in goats in Kajiado North District and cattle (6\%) compared to $1 \%$ in both sheep and goats in Isiolo District. Elsewhere; [16] reported 15\% in cattle, 4.9\% sheep and $2.4 \%$ in goats in Libya, and [17] from their study in Ethiopia reported $35.15 \%$ in cattle, $11.78 \%$ in sheep and $4.9 \%$ in goats. The differences in the findings of this study and other reports elsewhere can be attributed to differences in a number of factors including management, climate, animal population/stocking rate, economic activities and level of awareness on zoonotic parasites as argued by [18].

In this study, more goats (6.1\%) than sheep (4.9\%) were infected with hydatid cysts and this could be as a result of high number of goats slaughtered compared to sheep. A similar finding was reported by [19] in Ngorongoro, Tanzania where $22.2 \%$ goats and $16.6 \%$ sheep were infected with hydatid cysts. However, several 
studies both locally and globally have reported different findings. In Kenya, for example, Addy et al. (2012) reported that 16.5\% sheep and $10.8 \%$ goats were infected in Maasailand whereas [5] reported $19 \%$ sheep and 13\% goats in Kajiado North district and 4.5\% sheep and $2 \%$ goats had hydatid cysts in both Kisumu East and West districts. Elsewhere, [20] reported 42.5\%, and 33.3\% in sheep and goats, respectively in Soroti, Uganda and in the Delta region of Egypt [21] reported 6.4\% infection rate in sheep compared to $5.27 \%$ for goats. The lower incidences in goats has been attributed to their mode of feeding, being browsers they are less likely to come in contact with the parasite eggs compared to grazers like sheep and cattle. However, for this particular study more goats $(27,828)$ were slaughtered compared to sheep $(7,943)$ leading to higher prevalence in goats.

The prevalence of sheep in this study was lower than $16 \%$ reported in Addis Ababa, Ethiopia [18] but higher than 0.33\% was reported from a retrospective study of abattoir data by [3] in Egypt. For goats, 6.4\% prevalence for this study is higher than 4.9\% reported in Ethiopia [17]. The discrepancies in the prevalence of Echinococcus infection in small domestic ruminants in the above studies could be due to differences in economic activities eg pastoral, mixed or agricultural communities, environmental conditions and source of data.

Only liver and lung were organs found to be infected in this study and this agrees with other similar studies [6,21] though [15] reported infections in other viscera. The organ infection may depend on their anatomy or physiology as well as animal species [17]. This could be due to the presence of dense capillary network in these organs that prevent the ecchinococcus embryos that pass through the portal route and hence therefore harbouring them [22].

Generally, more livers (2.6\% goats; $3.4 \%$ sheep) than lungs (2.3\% goats; $2.7 \%$ sheep) were condemned due to hydatid cyst infection. Similarly, [5] reported higher estimates for liver $(12.1 \%)$ compared to $6.5 \%$ in sheep in Kajiado North district, however, he recorded $6.7 \%$ lung infection compared to $6.2 \%$ for liver in goats. In a retrospective study carried out on Government abattoirs in Upper Egypt, $39.3 \%$ livers, $32.5 \%$ lungs and only $2.2 \%$ of other viscera were condemned due to infection [15].

In this study, generally there is a decreasing trend of hydatid infection shown by the decreasing trend of organs condemned. The decreasing trend could be attributed to a number of factors identified during the interview of stakeholders that include strict measures on disposal of condemned organs, reduced home slaughter of sheep and goats, increase level of awareness on parasitic zoonoses and regular deworming of dogs.

Once an organ is found to be infected with hydatid cysts, it is condemned and therefore loss of revenue from condemnation. Based on findings from this study, a total of KSh 216,925 (Liver=KSh 195,400; Lung= KSh21, 525) was lost during the 5-year study period as a result of condemnation of organs from sheep and goats due to hydatidosis. This figure is higher than what was recorded in a five-year retrospective study (between 2005-2009) in sheep and goats carried out in Kisumu West and East Districts of KSh 141,625 (Liver=KSh 117,650; Lung= KSh 23,975) and Isiolo District of KSh 13,050 (Liver=KSh 9,200; Lung=KSh 3,850) [5]. The differences in the direct loss due to organ condemnation may be attributed to differences in the total number of animals slaughtered and climatic conditions in the study areas. Belgut Sub-County has a cool and wet climate that may favor the survival of the parasite eggs and larvae in the environment and the possible infection of sheep and goat during feeding. Similarly, higher prevalence in sheep and goats has been reported in temperate regions for example $47-81.9 \%$ in sheep and $71.9 \%$ in goats were found to have been infected with hydatid cysts in Italy [23].

\section{Conclusion}

Echonicoccus granulosus parasite is prevalent in Belgut SubCounty. It is one of the causes of organ condemnation in small domestic ruminants. Liver and lung of sheep and goats were the organs found to be infected and these led to their condemnation and hence direct economic losses to butchers.

\section{Recommendations}

The following recommendations can be made based on the findings of this study

- Regular deworming of dogs in the area to reduce environmental contamination by the parasite eggs.

- $\quad$ Proper and strict disposal of rejected/condemned organs due to hydatidosis to restrict dogs accessing them.

- Increase public education and awareness on parasitic zoonoses and the risks associated with consuming un-inspected meat, as required by the Meat Control Act (cap 356).

- $\quad$ Fencing off of abattoirs to restrict access by dogs and perhaps other animals may present an additional safety measure.

\section{Acknowledgement}

None.

\section{Conflicts of Interest}

No conflict of interest.

\section{References}

1. Ansari Lari M (2005) A retrospective survey of Hydatidosis in livestock in Shiraz, Iran, based on abattoir data during 1999-2004. Vet Parasitol 133(1): 119-123.

2. Haftu and Kebede (2014) Study on Prevalence and Economic Significance of Bovine Hydatidosis in Bako Municipal Abattoir, West Shoa Zone, Oromiya Regional State. Journal of Veterinary Science \& Technology 5: $1-5$.

3. Haridy FM, Ibrahim BB, Elshazly AM, Awad SE, Sultan DM, et al. (2006) Hydatidosis granulosus in Egyptian slaughtered animals in the years 2000-2005. J Egypt Soc Parasitol 36(3): 1087-1100.

4. Wahlers K, Menezes CN, Wong ML, Zeyhle E, Ahmed ME, et al. (2012) Cystic echinococcosis in sub-Saharan Africa. Lancet Infect Dis 12(11): 871-880.

5. Odero Joseph, Japhet Magambo, Eberhard Zeyhle, Helen Kutima, Lucy Ndahi, et al. (2015) Prevalence of cystic echinococcosis and its economic 
significance in slaughtered livestock in Kisumu east/west and Isiolo districts of Kenya. Int J Info Res and Rev 2: 719-725.

6. Wyckliff $\mathrm{N}$ and Chepkirui E (2017) Prevalence and associated economic losses of Bovine Hydatidosis in selected abattoirs in Kericho, Kenya- an analysis of abattoir data. Int J Vet Sci 6(3): 163-167.

7. Sariozkan S and Yalcin C (2009) Estimating the production losses due to cystic echinococcosis in ruminants in Turkey. Veterinary Parasitol 163(4): 330-334.

8. Wachira TM, Bowles J, Zeyhle E and McManus DP (1993) Molecular examination of the sympatric existence and distribution of sheep and camel strains of Echinococcus granulosus in Kenya. AJ Trop Med and Hyg 48(4): 473-479.

9. Addy A, Alakonya A, Wamae N, Magambo J, Mbae C, et al. (2012) Prevalence and diversity of cystic echinococcosis in livestock in Maasailand, Kenya. Parasitol Res 111(6): 2289-2294.

10. Macpherson CNL (1983) An active intermediate host role for man in the life cycle of Echinococcus granulosus in Turkana, Kenya. Am J Trop Med Hyg 32(2): 397-404.

11. Food and Agricultural organization (1982) Echinococcosis/Hydatidosis: Surveillance, Prevention and Control. FAO/UNEP/WHO Guidelines. $\left(1^{\text {st }}\right.$ Edn), FAO, Rome, 147.

12. Torgerson PR and Budke CM (2003) Echinococcosis, an international public health challenge. Res Vet Sci 74(3): 191-202.

13. Budke CM, Deplazes P and Torgerson PR (2006) Global socioeconomic impact of cystic echinococcosis. Emerg Infect Dis 12(2): 296-303.

14. Kenya National Bureau of Statistics (2010) The 2009 Kenya Population and Housing Census Counting Our People for the Implementation of Vision 2030 VOLUME. Population of persons as per the Districts. Kenya.
15. Mosaab Omar, Sultan K, Haridy M and Omran A (2013) Prevalence of cystic echinococcosis in slaughtered ruminants in different abattoirs, Upper Egypt. American Journal of Animal and Veterinary Sciences 8(3): 117-121.

16. Kassem HH, Abdel-Kader AM and Nass SA (2013) Prevalence of hydatid cysts in slaughtered animals in Sirte, Libya. J Egypt Soc Parasitol 43(1): 33-40.

17. Fromsa A and Jobre Y (2011) Infection prevalence of hydatidosis (Echinococcus granulosus, Batsch, 1786) in domestic animals in Ethiopia: A synthesis report of previous surveys. Ethiop Vet J 15: 11-33.

18. Kebebe Erbeto, Girma Zewde and Bersissa Kumsa (2010) Hydatidosis of sheep and goats slaughtered at Addis Ababa Abattoir: prevalence and risk factors. Trop Anim Health Prod 42(5): 803-805.

19. Miran MB, Kasuku AA and Swai ES (2017) Prevalence of echinococcosis and Taenia Hydatigena cysticercosis in slaughtered small ruminants at the livestock-wildlife interface areas of Ngorongoro, Tanzania. Vet World 10(4): 411-417.

20. Nyero D, Zirintunda G, Omadang L and Ekou J (2015) Prevalence of hydatid cysts in Goats and sheep slaughtered in Soroti Municipal Abattoir, Eastern Uganda. Afri J Parasitol and Res 2(9): 148-151.

21. Sabri JH, Hassan MA, Ramadan MY and Khalifa NO (2005) Hydatidosis in sheep, Goats and human contacts. Benha J Vet Med 16: 2-2.

22. Esatgil MU and Tuzer E (2007) Prevalence of hydatidosis in slaughtered animals in Thrace, Turkey. Turkiye Parazitol Derg 31(1): 41-45.

23. Grosso G, Gruttadauria S, Antonio B, Marventano S and Mistretta A (2012) Worldwide epidemiology of liver hydatidosis including the Mediterranean area. World J Gastroenterol 18(13): 1425-1437. 